\title{
Study of the Behavior of Black Currant Varieties and Elites against Diseases under the Climatic Conditions of Baia Mare
}

\author{
Lucia MIHALESCU ${ }^{1 *}$, Oana MARE ROȘCA ${ }^{1}$, Zorica VOȘGAN ${ }^{1}$, Monica MARIAN ${ }^{1}$, Aurel MAXIM ${ }^{2}$, Mirela \\ CORDEA $^{2}$, Beatrice SZILAGYI ${ }^{2}$ \\ ${ }^{1}$ Department of Biology. Technical University of Cluj Napoca, North University Center of Baia Mare, \\ no.76 Victoriei Street, Baia Mare, Romania; \\ ${ }^{2}$ University of Agricultural Sciences and Veterinary Medicine, Cluj-Napoca, Mănăştur St., no. 3-5, \\ 400372 Cluj-Napoca, Romania; \\ * corresponding author: luciamihalescu@yahoo.com
}

Bulletin USAMV series Agriculture 72(1)/2015

Print ISSN 1843-5246; Electronic ISSN 1843-5386

DOI 10.15835/buasvmcn-agr: 10554

\begin{abstract}
Current trends exhibited worldwide to replace some food and therapeutic products that were synthetically obtained with similar extracts from fruits and plants, put fruit shrubs into a new light. They are relatively easily adapting to various culture conditions and systems. Fruits of fruit shrubs are an important provider of raw material that is valuable for obtaining some natural products with high food value. The aim of this experimental study was to estimate the resistance off 17 elites of black currants versus the attack of the pathogen agents, in order to expand them in culture. The experimental study was performed at a farm in Coltau, located $12 \mathrm{~km}$ of Baia Mare. Their behavior against mildew, anthracnose and rust was monitored. The inspections were made during the years of 2011 and 2012, observing the leaves and calculating the frequency, intensity and attack degree. Among the 17 studied variants, the most resistant to mildew, anthracnose and rust proved to be the variant no.4, followed by the variants no.7, 8, 9, and 17, which are recommended to be extensively used in culture. The most sensitive plants were the variants 5 and 6 which had over $60 \%$ of leaves attacked on $25-50 \%$ of their surface. Higher anthracnose attack appeared at the elites no.10,13,15, 16, having over $20 \%$ of leaves attacked with the intensity of over $50 \%$.
\end{abstract}

Keywords: attack, disease, resistance, sensitive, variants.

\section{INTRODUCTION}

Black currant fruits are a source of important raw material for obtaining natural products (Chira et al., 2006). Although if prefers light, black currant grows and has a good development too on northern exposed terrains in the regions with strong insolation (Badescu et al., 1984). The shrub is easily multiplied and maintained in culture, early yields, and gives rich fruits per area unit (Mihut, 2004).

\section{AIMS AND OBJECTIVES}

The aim of the study was to assess the resistance of some elites of black currant against the attack of pathogenic agents, in order to cultivate them extensively. The followed objectives were based on the appreciation of resistance to mildew, anthracnose and rust, respectively; the behavior versus the pedoclimate conditions of the region of the 17 studied elites. They were analyzed versus the Tsema and Record control varieties.

\section{MATERIALS AND METHODS}

Theexperimentalstudywasperformedatafarm in Coltau, located $12 \mathrm{~km}$ South of Baia Mare, where the climatic conditions are identical with those in the city. The black currant plantation comprises of 17 variants in four repetitions each, randomly set. Their behavior against mildew, anthracnose and rust was monitored. The inspections were made 
during the years of 2011 and 2012, observing 100 leaves, as 25 leaves/repetitions each, calculating the frequency, intensity and degree of attack. The agrometeorological data were recorded using the AgroExpert with the Baia Mare phytosanitary inspectorate.

\section{RESULTS AND DISCUSSION}

For reaching these objectives, a series of monitoring and research both in the farm and in the laboratory were carried out during the two research years of 2011-2012. The climate conditions during the summer of 2011 with temperatures of July of $35.5-37.4^{\circ} \mathrm{C}$ and medium precipitations during the first part of the year, favored a pretty much strong attack of rust. The most sensitive plants were the variants 5 and 6 which had over $60 \%$ of leaves attacked on $25-50 \%$ of their surface. The variants no.4, 7, 8, 9, 17 were the most resistant to rust. There were no records of strong mildew attack; the variant no. 4 had the best behavior. The elites no.10, 13, 15, 16 presented anthracnose symptoms, having over $20 \%$ of leaves attacked with the intensity of over $50 \%$. The highly dry conditions of the year 2012 did not favor the development of the rust attack. As about the mildew and anthracnose attack, we found that the frequency as well as the intensity of the attack on leaves had lower values, comparatively with those recorded in 2011. Higher sensitivity was signaled at anthracnose, where the elites no.13, 16 registered an attack with the intensity of $20 \%$ on over $15 \%$ of their leaves. So, taking account of the behavior of the 17 elites during the two research years, we found that the most resistant to mildew, anthracnose and rust proved to be the variants no.4, 7, 8, 9, and 17, which are recommended to be extensively used in culture. The other monitored variants presented medium or high sensitivity.

\section{CONCLUSION}

Obtaining resistant varieties, including shrubs, is a necessity both for the great fruit growers and the private farms. Among the 17 studied variants, the variants no. 4, 7, 8, and 17 proofed to be the most resistant to mildew, anthracnose and rust; they are recommended to be cultivated.

\section{REFERENCES}

1. Badescu G, Constantinescu M, Badescu L (1984). Fructele si sanatatea, Ed. Ceres, Bucuresti, 38-46.

2. Chira L, Chereji V, Roman M (2006). Cultura coacazului negru si rosu, Ed. MAST, 54-58.

3. Mihut E (2004). Cultura arbustilor fructiferi, Ed. Ceres, 42 